\title{
Prosodic evidences to sentential negation in Brazilian Portuguese
}

\author{
Lílian Teixeira de Sousa \\ Department of Linguistics, University of Campinas, Brazil \\ https://doi.org/10.36505/ExLing-2010/03/0045/000165
}

\begin{abstract}
Brazilian Portuguese (BP) permits at least three kinds of sentential negation - Neg1 (Não VP), Neg2 (Não VP Não) and Neg3 (VP Não). The theme of this paper is the nature of this variation. We will try to demonstrate that at least in some contexts Neg2 exhibit properties associated with presupposed denial, reflecting fundamental differences in relation to canonical negation (Neg1). Some contexts show the incompatibility of $\mathrm{Neg} 2$ and Neg1. We believe this incompatibility can be explained by presupposition and scope. The aim of this paper is try to show the relation between the negation structures in BP and the pragmatic content.
\end{abstract}

Key words: Negation, Brazilian Portuguese, pragmatic, prosody

\section{Introduction}

Brazilian Portuguese (BP), as (1) shows, permits at least three kinds of negation structures (cf. Alkmim 1999, Schwenter 2005, Cavalcante 2007):

(1) a. Eu não/num ${ }^{l}$ gosto de doces

I Neg like of candy-pl

'I don't like candies.'

b. Eu não gosto de doces não.

I Neg like of candy-pl $\mathrm{Neg}_{2}$

c. Gosto de doces não.

Like-1ps of candy-pl $\mathrm{Neg}_{3}$

The theme of this paper is the nature of variation on sentential negation in BP. We will try to demonstrate that at least in some contexts $\mathrm{Neg}_{2}$ and $\mathrm{Neg}_{3}$ in BP exhibit properties associated with presupposed denial, reflecting fundamental differences in relation to canonical negation (1a). By analyzing some contexts in which the incompatibility of $\mathrm{Neg}_{2}, \mathrm{Neg}_{3}$ and canonical negation $\left(\mathrm{Neg}_{1}\right)$ can be explained by presupposition and the notion of focus as theoretical basis, our analysis captures various aspects that support the identificational focus construction hypothesis to $\mathrm{Neg}_{2}$ and $\mathrm{Neg}_{3}$.

Another goal of these study is the identification of an analytic model for the interaction between syntax and phonology in the context of the

ExLing 2010: Proceedings of 3rd Tutorial and Research Workshop on Experimental Linguistics, 25-27 August, Athens, Greece 
expression of the informational structure, trying to capture the way syntax influences the prosodic component of the grammar and vice-versa as well as the composition of the meanings in the expression of the informational structure, either universally or parametrically.

\section{On Syntax}

$N \tilde{a} o_{2}$ in $(1 \mathrm{~b}-\mathrm{c})$ is different from $n \tilde{a} o_{1}$ since it is phonologically autonomous while $n \tilde{a} o_{1}$ can surface as a clitic, num (cf. Cavalcante 2007, contra Martins 1997 and Fonseca 2004), i.e. $n \tilde{a} o_{2}$ is stronger than $n \tilde{a} o_{1}$ as only $n \tilde{a} o_{1}$ can be reduced:

(2) Ele num comprou a casa (não ${ }^{*}$ *num) he not.CL bought the house NEG

"He has not bought the house"

As shown follow Neg3 is ungrammatical in embedded sentences, in sentences with subject and in interrogative sentences:

(3) a. *Eu sei que livro é esse não.

I know which book is this not

b. *O João acha que você deve viajar não

the João think th you should travel.INF not

c. * O João comprou cigarro não

the João buy.PAST cigarette not

d. * Quem você conheceu não?

Who you know not

\section{On pragmatics}

In $\mathrm{BP}, n \tilde{a} o_{2}$ necessarily contributes a particular interpretive effect when it occurs. It cannot surface in simple, unmarked declaratives - this is the domain of $n \tilde{a} o_{l}$ (4) (cf. Schwenter 2005, Cavalcante 2007).

(4) a. A Maria não ${ }_{1} /$ num vai no teatro [= simple declarative] the Mary not not.CL go in-the theater

"Mary is not going to the theatre"

b. \%A Maria não $/$ num vai no teatro não $o_{2}[\neq$ simple declarative]

c. \%A Maria vai no teatro $n \tilde{a} o_{2}[\neq$ simple declarative]

Neg2 occurrence depends nevertheless of common ground, inferable contexts. The following examples show some instances of Neg2. 
(5) [Speaker sees interlocutor blowing on some soup]

Não está quente não!

'It's not hot!'

In (5), the speaker sees the interlocutor blowing on the soup and infers that the interlocutor assumes the soup to be hot, but he/she knows that it is not hot and tells it to the interlocutor. Using Neg2, the speaker is correcting a presupposition and introducing new information at the same time.

Now, pay attention to the example below. In this case, the whole sentence bears out the new information, there is no common ground and no presupposition being denied and Neg2 is not suitable.

(6)[speaker going to the school and suddenly remembers she forgot to do her homework]

Nossa! Eu não fiz os exercícios (\#não)!

'Oh My! I didn't do the (pl) homework (\#not)!'

Interesting data is shown below.

(7)[same situation as (6)]

A: Você fez os exercícios, né?

'You did the homework, right?

B1: Não fiz não!

'No, I didn't!'

B2: (Não) eu não consegui (\#não).

'(No.) I couldn't.'

In these data, there are two distinct answers to the question "Você fez os exercícios, né?" (You did the homework, right?). In B1, the presupposition that she did the homework is denied, and Neg2 is ok. In B2, new information is introduced by the sentence "Eu não consegui", in this case only the Neg1 is employed.

\section{Some Results}

The methodological analysis is composed by prosodic analysis of sentences produced by four native speakers. We paid special attention to pitch contour. Prosodic structures also reinforce the contrast in the negation possibilities. The entoacional analysis shows that in $\mathrm{Neg}_{2}$ (1b) nothing receives prominence, the clause-final $n \tilde{a} o$ has the ordinary final sentence intonation pattern. $\mathrm{Neg}_{1}$ item can receive prominence or not, but if não receives prominence the interpretation is informational focus with no presupposition. 
$\mathrm{Neg}_{3}$ is never prominent but, unlike $\mathrm{Neg}_{2}$, this item can be phonologically separated of the sentence by pause or boundary tone.

\section{Proposal}

According Kiss (1998), the identificational focus involves the syntactic projection of the Focus head. In the framework assumed here, this mean that in identificational focus construction, the Focus head acts as a probe and undergoes the Agree operation with the focused expression. Taking those assumptions, we consider that the $\mathrm{Neg}_{3}$ unlike $\mathrm{Neg}_{2}$ is not an integrated item, act as a focus head in left periphery attracting the VP to Spec/Foc.

\section{Notes}

1. In BP, the pre-verbal negative item can be pronounced by não or by the clitic num. But the post-verbal negative element can only be the form $n \tilde{a} o$.

\section{References}

Alkmim, M.G.R. de. 2001. As Negativas Sentenciais no Dialeto Mineiro: uma Abordagem Variacionista, 260 p. Tese de Doutorado, UFMG.

Careno, M.F., Peter, M.M.T. 1994. Observações sobre o uso da estrutura negativa. Papia. V3, n.2. p 98-102.

Chomsky, N. 2000. Minimalist inquiries: the framework. In Step by step, ed. R. Martin, D. Michaels and J. Uriagereka, 89-156. Cambridge, Mass.: MIT Press.

Furtado Da Cunha, M.A. 1996. Gramaticalização dos Mecanismos de Negação em Natal. IN: Martelotta, Votre \& Cezário (org.) Gramaticalização no Português do Brasil: uma abordagem funcional. R.J.: Tempo Brasileiro. p. 167-189.

Jackendoff, R.S. 1972. Semantic interpretation in generative grammar. Cambridge, Mass: MIT Press.

Roncarati, C.N. 1997. A negação no Português falado. In: Macedo, A.T. et al. (Orgs.). Variação e Discurso. RJ: Tempo Brasileiro. p.65-102.

Schwegler, A. 1983. Predicate Negation and word-order change - A problem of multiple causation. Lingua 61: s97-334.

Schwenter, S.A. 2005. The pragmatics of negation in Brazilian Portuguese. Lingua 115. p. 1427-1456. 